\title{
BRYOPHYTES OF SALINE AREAS IN THE PANNONIAN REGION OF SERBIA AND CROATIA
}

\author{
Beáta Papp ${ }^{1 *}$, Antun Alegro ${ }^{2}$, Peter Erzberger ${ }^{3}$, Erzsébet Szurdoki ${ }^{1}$, \\ Vedran ŠEgota ${ }^{2}$, Marko SABovlJEVIĆ ${ }^{4}$ \\ ${ }^{1}$ Department of Botany, Hungarian Natural History Museum, \\ H-1431 Budapest, Pf. 137, Hungary, *0appbea@nhmus.hu \\ ${ }^{2}$ Division of Botany, Department of Biology, Faculty of Science, University of Zagreb, \\ Marulićev trg 20/II, HR-10000 Zagreb, Croatia \\ ${ }^{3}$ Belziger Str. 37, D-10823 Berlin, Germany \\ ${ }^{4}$ Institute of Botany and Botanical Garden, Faculty of Biology, University of Belgrade, \\ Takovska 43, 11000 Belgrade, Serbia
}

Papp, B., Alegro, A., Erzberger, P., Szurdoki, E., Šegota, V. \& Sabovljević, M. (2016): Bryophytes of saline areas in the Pannonian region of Serbia and Croatia. - Studia bot. hung. 47(1): 141-150.

\begin{abstract}
Altogether 40 species ( 5 liverworts and 35 mosses) were collected in the studied saline grasslands in the Pannonian region of Serbia and Croatia. The following bryophyte species are characteristic both in the Serbian and Croatian sites: Barbula unguiculata, Brachythecium albicans, Bryum algovicum, B. dichotomum, B. ruderale, Didymodon sicculus, Drepanocladus aduncus, Microbryum davallianum, $M$. floerkeanum, Phascum cuspidatum, Protobryum bryoides, and Pseudocrossidium hornschuchianum. Most of these are typical elements of the bryophyte assemblages living on the saline-alkaline grasslands of the Danube-Tisza Interfluve in Hungary. Didymodon sicculus is reported for the first time in Croatia here. Microbryum floerkeanum is included in the Red data book of European bryophytes. In addition, in the studied Serbian saline sites another European red-listed species, Entosthodon hungaricus, is also present. Two thalloid liverworts, rare in SE Europe, Oxymitra incrassata and Riccia nigrella, were found in one Serbian site.
\end{abstract}

Key words: liverworts, mosses, new national record, SE Europe, threatened species

\section{INTRODUCTION}

The salt grasslands of the Pannonian region are the westernmost representatives of this habitat of the Eurasian steppe zone and they are the largest in East Central Europe; about 5,500 $\mathrm{km}^{2}$ in Hungary (MOLNÁR 1997). They occur mainly in the Great Hungarian Plain, in the former inundation areas of the Danube and Tisza rivers, and in the depressions of the sand and loess plateaus. However, near the Hungarian border in Serbia and Croatia some small extension remnants of saline areas can also be found, which form a single unit with the Hungarian salt grasslands. These are fragmented areas embedded in a typical agricultural landscape.

Pannonic salt steppes and salt marshes are priority habitat types in Europe according to the European Union Habitats and Species Directives (EEC 1992).

Studia botanica hungarica 47(1), 2016 Hungarian Natural History Museum, Budapest 
The most important condition of the formation of such areas is the relatively high level of saline groundwater under continental or semi-arid climate (Molnár 1997). Most of the Pannonic salt grasslands were formed in the Holocene (MOLNÁR 1997). The water regime of the alkali soils is very extreme, because the salt content is high near the surface. Therefore there is a close correlation between microrelief, water regime, salt content, soil properties and the floristical composition, which resulted in a mosaic-like appearance of the plant communities (MOLNÁR 1997). The marginal, transitional or border zones of various communities are advantageous for the establishment of bryophytes. Among tussocks on the bare soil surface rich bryophyte vegetation can be found. Mainly in spring several colonist species appear (PAPP and RAJCZY 2000).

Whereas in Hungary the bryophyte flora of salt grasslands is well-explored (ORBÁN 1982, PAPP and RAJCZY 1999, 2000), in the southern neighbouring countries salt areas are bryologically neglected habitat types. In Serbia, there was an earlier investigation on the cryptogam flora of the surroundings of Senta town carried out by János Guelmino in the 1970s (GUELMINo 1973). His compilation contained only 12 bryophyte species collected from saline areas. The specimens were identified by the Hungarian bryologists István Győrffy and Ádám Boros. Later on, another species, Riccia nigrella, was detected by Beáta Papp in an Oxymitra incrassata specimen collected by Guelmino (SABOVLJEvić et al. 2010). Guelmino's specimens are deposited in the Bryophyte Collection of the Hungarian Natural History Museum, Budapest (BP). In Croatia there were no earlier bryological investigations in salt grasslands.

\section{MATERIAL AND METHODS}

\section{Study area}

The investigated saline grasslands in Serbia are situated around Senta town at Trešnjevac, Velebit, and Padej villages, while in Croatia at Trpinja village (Fig. 1). These are flat areas at low elevation (80-100 m a.s.l.) characterised by continental climate with high daily and yearly temperature fluctuations as well as relatively low air humidity. Although during spring large areas are covered by water, drought is frequent in summer (Guelmino 1968, Topić \& Vuković 2010 Zaninović 2008).

In the grasslands around Senta town in Serbia the main species of the lower, wetter areas are Bolboschoenus maritimus (L.) Palla, Eleocharis palustris (L.) R. et Sch., and Juncus gerardii Loisel., while on the drier parts at somewhat higher elevations Puccinellia distans (L.) Parl. subsp. limosa (Schur) Jáv., Agrostis stolonifera L., Festuca pseudovina Hackel ap. Wiesb. are predominant. The lowest places are covered by the most heavily salt-affected (and salt-tolerant) plant community with the predominance of Camphorosma annua Pallas (Guelmino 1968). 
The surrounding of Trpinja village in Croatia is a typical agricultural area with the dominance of arable fields criss-crossed by a network of channels. The pastures with a mosaic of salt tolerant plant communities are spread on a surface of 4.5 ha, but the characteristic halophytic association Camphorosmetum annuae Rapaics ex Soó 1933 occupies not more than 1.5 ha. Beside Camphorosma annua, some other plant species characteristic for Pannonic salt steppes are Puccinellia distans subsp. limosa, Aster tripolium L. subsp.pannonicus (Jacq.) Soó, Plantago tenuiflora Waldst. et Kit., Podospermum canum C. A. Mey., Carex divisa Huds., Achillea setacea Waldst. et Kit. and some others. Water, remaining in shallow depressions, enables the formation of hygrophilous communities dominated by Juncus compressus Jacq. (Topić and Vuković 2010).

The salt pastures at Trpinja are included in the NATURA 2000 network as a site for priority habitat type 1530 (Pannonic salt steppes and salt marshes) (EEC 1992). The site is also considered as Important Plant Area and proposed for protection as Special reserve of grassland vegetation (IUCN category IV) with the purpose of protection of rare and in Croatia unique vegetation of continental salt habitats (BORŠIĆ et al. 2011).

\section{Site details}

1. Serbia, Vojvodina, N Banat, at Trešnjevac (Oromhegyes) village near Senta town, 45.988583 ${ }^{\circ} \mathrm{N}, 20.008944^{\circ} \mathrm{E}, 85 \mathrm{~m}, 06.04 .2010$. - 2. Serbia, Vojvodina, N Banat, at Velebit village near Senta town, $46.010772^{\circ} \mathrm{N}, 19.952594^{\circ} \mathrm{E}, 90 \mathrm{~m}, 06.04 .2010$. - 3. Serbia, Vojvodina, N Banat, at Padej village near Senta town, $45.841333^{\circ} \mathrm{N}, 20.164833^{\circ} \mathrm{E}, 80 \mathrm{~m}, 06.04 .2010$. - 4. Croatia, W Srijem, Trpinja village, $45.427027^{\circ} \mathrm{N}, 18.900694^{\circ} \mathrm{E}, 100 \mathrm{~m}, 12.05 .2013$.

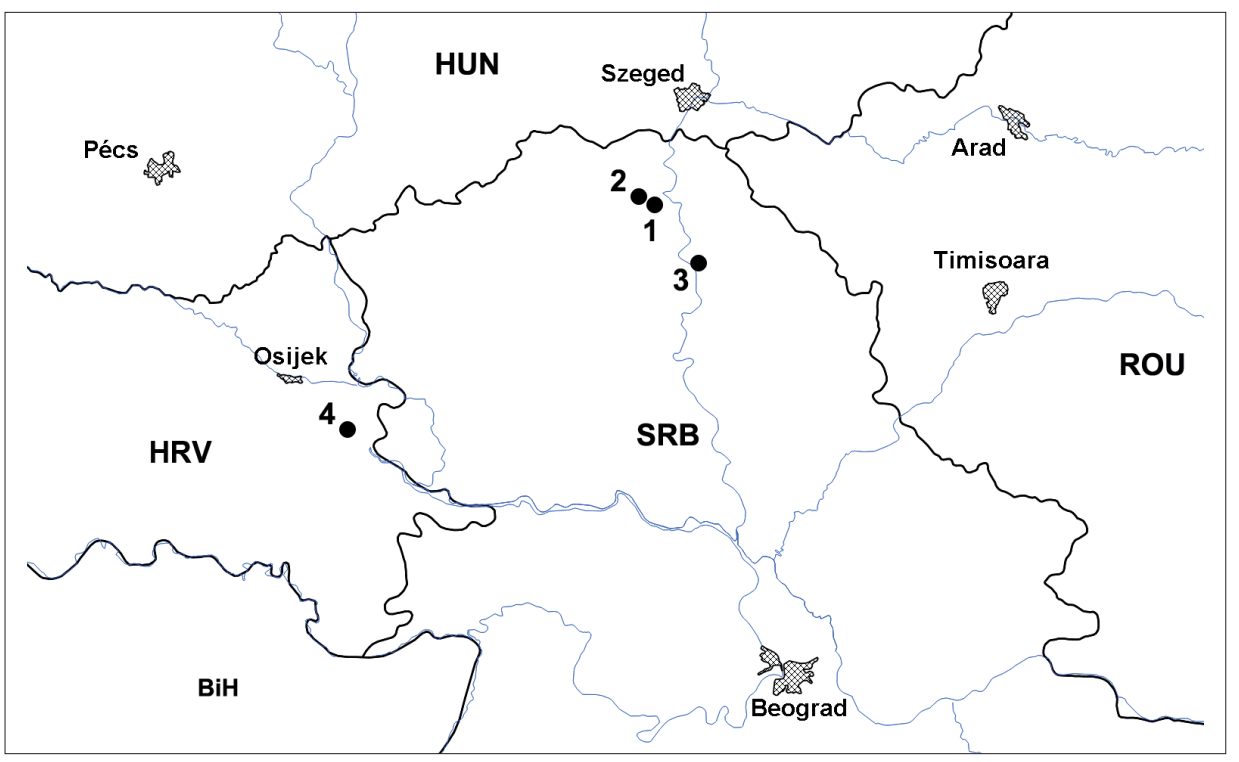

Fig. 1. Location of the investigated sites. 
Methods

The specimens are deposited in the Herbarium of the Hungarian Natural History Museum, Budapest (BP) and the Herbarium Croaticum of the University of Zagreb (ZA). Nomenclature follows GROLLE and LONG (2000) for liverworts and Hill et al. (2006) for mosses. European distribution of the species is given according to DüLL $(1983,1984,1985)$.

\section{RESULTS}

Altogether 40 species ( 5 liverworts and 35 mosses) were collected in the investigated saline grasslands, 19 at Trešnjevac, 19 at Velebit, 27 at Padej in Serbia, and 17 at Trpinja in Croatia, respectively. The list of bryophytes found is shown in Table 1 .

\section{DISCUSSION}

All of the species from the salt grasslands around Senta town recorded by Guelmino (1973) were re-found in the studied sites in Serbia. These were the following: Oxymitra incrassata, Riccia ciliifera, $R$. nigrella, $R$. sorocarpa, Barbula unguiculata, Brachythecium albicans, Bryum alpinum, Entosthodon hungaricus, Phascum cuspidatum, Polytrichum juniperinum, Protobryum bryoides, Pterygoneurum ovatum, Tortula lanceola.

Many sub-Mediterranean and sub-Atlantic bryophyte species are characteristic at the sites like Bryum ruderale, Didymodon sicculus, D. vinealis, Microbryum curvicollum, M. davallianum, M. floerkeanum, Protobryum bryoides, and Pseudocrossidium hornschuchianum. A continental, Mediterranean element, Entosthodon hungaricus can also be mentioned here. Besides these, species of the temperate zone of Europe also occur like Barbula unguiculata, Bryum algovicum, $B$. dichotomum, Phascum cuspidatum, Pterygoneurum ovatum, and in wetter places Brachythecium mildeanum and Drepanocladus aduncus. A subboreal species, Brachythecium albicans, is also a constant element of the bryophyte assemblage of the investigated saline grasslands. Most of the above-mentioned species are calcicolous and they are also characteristic elements of the bryophyte vegetation living on the salt grasslands of the Danube-Tisza Interfluve in Hungary, where the lime content in the soil is usually also high (PAPP and RAJCZY 1999, 2000).

The bryophyte flora of the grasslands at Padej is different from the other studied sites. The bryophyte diversity is higher due to the occurrence of some additional Mediterranean and sub-Mediterranean thalloid liverworts (Oxymitra incrassata, Riccia ciliifera, $R$. nigrella) and mosses (Aloina ambigua, Bryum alpi- 
Table 1. List of species found at the studied sites.

\begin{tabular}{|c|c|c|c|c|}
\hline & $\begin{array}{c}\text { Trešnjevac, } \\
\text { Serbia }\end{array}$ & $\begin{array}{l}\text { Velebit, } \\
\text { Serbia }\end{array}$ & $\begin{array}{l}\text { Padej, } \\
\text { Serbia }\end{array}$ & $\begin{array}{l}\text { Trpinja, } \\
\text { Croatia }\end{array}$ \\
\hline \multicolumn{5}{|l|}{ Liverworts } \\
\hline Cephaloziella divaricata (Sm.) Schiffn. & & & + & \\
\hline Oxymitra incrassata (Brotero) Sergio et Sim-Sim & & & + & \\
\hline Riccia ciliifera Link ex Lindenb. & & & + & \\
\hline Riccia nigrella DC. & & & + & \\
\hline Riccia sorocarpa Bisch. & & & + & \\
\hline \multicolumn{5}{|l|}{ Mosses } \\
\hline Aloina ambigua (Bruch et Schimp.) Limpr. & & & + & \\
\hline Barbula unguiculata Hedw. & + & + & + & + \\
\hline Brachythecium albicans (Hedw.) Schimp. & + & + & + & + \\
\hline Brachythecium mildeanum (Schimp.) Schimp. & & + & & + \\
\hline Bryum algovicum Sendtn. ex Müll.Hal. & + & & + & + \\
\hline Bryum alpinum Huds. ex With. & & & + & \\
\hline Bryum caespiticium Hedw. & + & & & \\
\hline Bryum dichotomum Hedw. & + & & + & + \\
\hline Bryum ruderale Crundw. et Nyholm & + & + & & + \\
\hline Ceratodon purpureus (Hedw.) Brid. & & & + & \\
\hline Dicranella howei Renauld et Cardot & & & & + \\
\hline Dicranella varia (Hedw.) Schimp. & & & & + \\
\hline Didymodon acutus (Brid.) K. Saito & & + & + & \\
\hline $\begin{array}{l}\text { Didymodon sicculus M. J. Cano, Ros, García-Zamora } \\
\text { et J. Guerra }\end{array}$ & + & + & + & + \\
\hline Didymodon vinealis (Brid.) R. H. Zander & + & & & + \\
\hline Ditrichum flexicaule (Schwägr.) Hampe & & & + & \\
\hline Drepanocladus aduncus (Hedw.) Warnst. & + & + & + & + \\
\hline Entosthodon hungaricus (Boros) Loeske & + & + & + & \\
\hline Funaria hygrometrica Hedw. & & + & & \\
\hline Homalothecium lutescens (Hedw.) H. Rob. & + & + & & \\
\hline Microbryum curvicollum (Hedw.) R. H. Zander & + & + & & \\
\hline Microbryum davallianum (Sm.) R. H. Zander & + & + & & \\
\hline $\begin{array}{l}\text { Microbryum floerkeanum (F. Weber et D. Mohr) } \\
\text { Schimp. }\end{array}$ & + & + & & + \\
\hline Oxyrrhynchium hians (Hedw.) Loeske & + & & & + \\
\hline Phascum cuspidatum Hedw. & + & + & + & + \\
\hline Pleurochaete squarrosa (Brid.) Lindb. & & & + & \\
\hline Polytrichum juniperinum Hedw. & & & + & \\
\hline Protobryum bryoides (Dicks.) J. Guerra et M. J. Cano & + & + & + & + \\
\hline $\begin{array}{l}\text { Pseudocrossidium hornschuchianum (Schultz) R. H. } \\
\text { Zander }\end{array}$ & + & + & + & + \\
\hline Pterygoneurum ovatum (Hedw.) Dixon & + & + & + & \\
\hline $\begin{array}{l}\text { Rhynchostegium megapolitanum (Blandow ex F. } \\
\text { Weber et D. Mohr) Schimp. }\end{array}$ & & + & & \\
\hline Syntrichia ruralis (Hedw.) F. Weber et D. Mohr & & + & + & \\
\hline Tortula lanceola R. H. Zander & & & + & \\
\hline Tortula modica R. H. Zander & & & + & \\
\hline Weissia sp. & & & + & + \\
\hline
\end{tabular}


num). Riccia species and Bryum alpinum are characteristic members of the bryoflora of salt grasslands in the Hortobágy region of Hungary, where sulphate containing soils occur (BOROS 1968, ORBÁN 1982).

\section{New and interesting records}

Didymodon sicculus is a new element of the Croatian bryoflora. It was also reported for the first time in Serbia from this collection (PAPP et al. 2011). This species was described from southern Spain by CANo et al. (1996). It is a xerophytic plant, which occurs on dry, loamy, saline, and gypsiferous soils. At first, it was thought to be endemic to SE Spain, but later on, it was discovered in many Atlantic and Western Mediterranean regions like the Azores, Balearic Islands, Canary Islands, Algeria, France, Morocco, Portugal, Sicily (Ros et al. 2013). In SE Europe it is already known from Albania, Bulgaria, Greece, Montenegro, Serbia, Slovenia, and Turkey (Hodget s 2015). It also occurs in Hungary in saline areas of the Danube-Tisza Interfluve (unpublished data of Erzberger and Papp).

Microbryum curvicollum is a sub-Mediterranean species (DüLL 1984), rare in SE Europe; known only from Bulgaria (where it is data deficient (DD)), Croatia, Greece, Romania (where it is endangered (EN)), and Serbia (HodgetTs 2015). It is also red-listed in many Central European countries, e.g. Austria, Germany, Luxemburg, Netherlands, Poland, Slovakia, Switzerland (Hodgetrs 2015). It is a tiny moss and was probably overlooked. It was found in the Serbian sites at Trešnjevac and Velebit.

Microbryum floerkeanum was reported for the first time in Serbia from this collection (PAPP et al. 2012). It is a sub-Mediterranean, sub-Atlantic element (DüLL 1984), included in the data deficient category according to the Red data book of European bryophytes (ECCB 1995). Due to its minute size and seasonal appearance, it is frequently overlooked. In SE Europe it is known only from Bulgaria, Croatia, Serbia, and Romania (HoDGETTS 2015), where it is critically endangered (ŞTEFĂNUT, and Gora 2012). It was found both in the Serbian and Croatian investigated sites.

Entosthodon hungaricus is relatively abundant in the studied Serbian saline areas, but in general a rare species in Serbia and threatened due to its specific ecological features and degradation of its habitat. It is also a character species of the Hungarian saline grasslands (PAPP and RAJCZY 2000). It is a continental-Mediterranean species (DÜLL 1984), included in the rare (R) category according to the Red data book of European bryophytes (ECCB 1995). In SE Europe it is known only from Greece, Romania, and Serbia (HodgetTs 2015). It is endangered (EN) in Serbia (SABOVLJEVIĆ et al. 2004). It occurs in some Central European countries, where it is also red-listed, e.g. in Austria, Germany, Hungary, and Slovakia (Hodget Ts 2015). In southwestern Europe it is red-listed in the Canary Islands, Malta, and Spain. Besides these it is known from Portugal and Sicily (HodgetTs 2015). 
Oxymitra incrassata is a sub-Mediterranean thalloid liverwort (DüLL 1983) rare in SE Europe, and lacking or red-listed in many SE European countries (HodgetTs 2015). It is vulnerable (VU) in Bulgaria and Slovenia, critically endangered (CR) in Montenegro, missing from Bosnia and Herzegovina, the Republic of Macedonia, and the European part of Turkey (HodgetTs 2015). It was reported from Serbia by SABOVLJEVIĆ et al. (2010). A specimen collected by János Guelmino was found in the Herbarium of the Hungarian Natural History Museum, Budapest (BP). This publication has been overlooked by HodgetTs (2015), who erroneously reports it as missing from Serbia. It is also red-listed in all the Central European countries, where it occurs, e.g. Austria, Germany, Hungary, Poland, Slovakia, and Switzerland (HodgetTs 2015). Now the survival of the population in the salt grasslands at Padej is confirmed.

Protobryum bryoides is a sub-Mediterranean species (DüLL 1984). It is known from almost all SE European countries except Albania and Bosnia and Herzegovina, but endangered (EN) in Bulgaria and vulnerable (VU) in Romania and Slovenia (HodgetTs 2015). It is also red-listed in many Central European countries, e.g. Austria, Netherlands, Slovakia, Switzerland (HodgetTs 2015). Probably it is overlooked due to its seasonal appearance. It was found in all investigated sites, both in Serbia and in Croatia.

Pterygoneurum ovatum is vulnerable (VU) according to the red list of Serbia (SABOVLJEVIĆ et al. 2004). It is a species of the European temperate zone (DüLL 1984), and known from all SE European countries (HodgetTs 2015). It is also red-listed in many Central European countries, e. g. Austria, Germany, Luxemburg, Netherlands, and Switzerland (Hodget ts 2015). Probably it is also overlooked due to its seasonal appearance. It was relatively abundant in the studied Serbian saline areas on disturbed soil, mainly on the bank of channels.

Riccia nigrella is an Atlantic, Mediterranean thalloid liverwort (DüLL 1983). It was reported for the first time in Serbia by SABOVLJEVIĆ et al. (2010). It was separated from an $O$. incrassata specimen collected by János Guelmino in the 1970s, and deposited in the Herbarium of the Hungarian Natural History Museum, Budapest (BP). During our investigation it was re-found on the salt grasslands at Padej. It is known from almost all SE European countries except the Republic of Macedonia, Romania, and Slovenia (HodgetTs 2015), however it has mostly old records in many countries (BISCHLER et al. 1980, DragićEvić and Veljić 2006). From Croatia there is one recent record collected this year (leg. Vuković, Herbarium $\mathrm{ZA}$ ), in Bulgaria there are two recently known populations (pers. comm. Rayna Natcheva). In the Mediterranean part of Greece it is not rare (BLOCKEEL 2010, 2012, Erzberger 2006, SABovljević et al. 2008). In Central Europe it is known only from Switzerland, where it is vulnerable (VU) (HodGETTs 2015). 


\section{CONCLUSIONS}

During winter and in early spring, when large territories are under water because the soil cannot absorb rainfall, Drepanocladus aduncus is very abundant in the studied saline areas, while other bryophytes occur only sporadically at higher elevations, on drier spots. However, from March to April several colonist species appear mainly in the transitional zones of higher plant communities, and on bare soil among tussocks, e. g. Microbryum, Phascum, Protobryum, Pterygoneurum species, and Entosthodon hungaricus always with capsules, as well as species of the Bryum erythrocarpum complex with rhizoid gemmae like Bryum ruderale, and $B$. dichotomum with axillary propagules. These species can colonise very quickly the open soil surfaces owing to their intensive production of spores and vegetative propagules. In spots at higher elevation mainly pleurocarpous perennial species occur, e.g. Brachythecium albicans, Homalothecium lutescens.

In order to preserve the high bryophyte diversity of saline areas the maintenance of mosaic-like arrangements of higher plant communities and grasslands rich in bare soil surfaces is crucial. Sheep grazing is an important factor in the preservation of the structure of saline grassland. As the use of land is changing in Serbia and Croatia, agriculture, especially animal husbandry is declining, these grasslands are threatened by abandonment, which will cause the formation of more dense and uniform stands. The decrease of open soil surfaces and lack of disturbance are disadvantageous for the colonist bryophyte species. The bryophyte diversity would decrease and rarities or conservationally important species would disappear. In Croatia the saline areas are protected, however their extension is very small, surrounded by agricultural lands, hence active conservation management is important. In Serbia these saline areas are not protected and even their future cannot be predicted.

Acknowledgements - We are indebted to Jan Kučera (České Budejovice) for his help in confirmation of Didymodon sicculus specimens. We are grateful to Jani Marka (Tirana), Snežana Dragićević (Podgorica), Rayna Natcheva (Sofia) for the information on the distribution of Riccia nigrella. The study was supported by the bilateral projects of the Hungarian Academy of Sciences and the Serbian Academy of Sciences and Art (2010-2012, 2013-2015) titled "Investigations on cryptogam flora (bryophytes, lichens) and biodiversity in Serbia and Hungary, especially in the habitats of rare species".

Összefoglaló: 40 mohafajt (5 májmohát és 35 lombosmohát) találtunk szerbiai és horvátországi pannon szikes területek vizsgálatai során. A következő mohák mind a szerbiai, mind a horvátországi területeken előfordultak: Barbula unguiculata, Brachythecium albicans, Bryum algovicum, B. dichotomum, B. ruderale, Didymodon sicculus, Drepanocladus aduncus, Microbryum davallianum, Microbryum floerkeanum, Phascum cuspidatum, Protobryum bryoides és Pseudocrossidium hornschuchianum. Ezeknek a fajoknak a többsége a magyarországi Duna-Tisza közi szikeseknek is tipikus mohája. Egy faj, Didymodon sicculus, újnak bizonyult Horvátország mohaflórájára. A Micro- 
bryum floerkeanum szerepel az európai moha vörös könyvben. A szerbiai szikeseken egy másik európai moha vörös könyves faj, az Entosthodon hungaricus, is elöfordul. Az egyik szerbiai területen talált két telepes májmoha (Oxymitra incrassata és Riccia nigrella) pedig ritka Délkelet-Európában.

\section{REFERENCES}

Bischler, H., Jovet-Ast, S. and BAudoin, R. (1980): Hépatiques de la côte albanaise. - Cryptogamie Bryol, Lichénol. 1: 247-267.

BlockeEL, T. L. (2010): The bryophytes of Greece: new records and observations, 2. - Nova Hedwigia, Beih. 138: 129-146.

BLOCKEEL, T. L. (2012): Notes on the bryophytes of the schistose valleys of western Crete, including Asterella africana new to Greece, and an assessment of the conservation status of Rhamphidium purpuratum and Jungermannia handelii. - J. Bryol. 34: 292-296.

http://dx.doi.org/10.1179/1743282012y.0000000024

Boros, Á. (1968): Bryogeographie und Bryoflora Ungarns. - Akadémiai Kiadó, Budapest, 466 pp.

Boršić, I., Hruševar, D. and Posavec Vukelić, V. (2011): Posebni rezervat travnjačke vegetacije Trpinja - stručna podloga za zaštitu. - Državni zavod za zaštitu prirode (State Institute for Nature Protection), Zagreb, $52 \mathrm{pp}$.

Cano, M. J., Ros, R. M., Garcia-Zamora, P. and Guerra, J. (1996): Didymodon sicculus sp. nov. (Bryopsida, Pottiaceae) from the Iberian Peninsula. - The Bryologist 99: 401-406. http://dx.doi.org/10.2307/3244102

Dragićević, S. and Veljić, M. (2006): Pregled mahovina Crne Gore. - Prirodnjački Muzej Crne Gore, Podgorica, $99 \mathrm{pp}$.

DüLL, R. (1983): Distribution of the European and Macaronesian liverworts (Hepaticophytina). - Bryol. Beitr. 2: 1-115.

DÜLL, R. (1984): Distribution of the European and Macaronesian mosses (Bryophytina) I. - Bryol. Beitr. 4: 1-109.

DüLL, R. (1985): Distribution of the European and Macaronesian mosses (Bryophytina) II. - Bryol. Beitr. 5: 110-232.

ECCB (1995): Red data book of European bryophytes. - European Committee for Conservation of Bryophytes, Trondheim, $291 \mathrm{pp}$.

EEC (1992): Council Directive 92/43/EEC of 21 May 1992 on the conservation of natural habitats and of wild fauna and flora. - http://eur-lex.europa.eu/legal-content/en/TXT/?uri=CELEX: 31992L0043 (accessed: 2 June, 2016)

ERzberger, P. (2006): Contribution to the bryophyte flora of Chalkidiki, Greece. - Willdenowia 36: 515-525. http://dx.doi.org/10.3372/wi.36.36149

Grolle, R. and LonG, D. G. (2000): An annotated check-list of the Hepaticae and Anthocerotae of Europe and Macaronesia. - J. Bryol. 22: 103-140. http://dx.doi.org/10.1179/jbr.2000.22.2.103

Guelmino, J. (1968): Zenta és környékének növényei I. (Virágosok). [Plants of Senta and its surroundings I. (Phanerogams)]. - Grada za monografiju Sente 12: 3-155.

Guelmino, J. (1973): Zenta és környékének növényei II. (Virágtalanok). [Plants of Senta and its surrounding II. (Cryptogams)]. - Grada za monografiju Sente 13: 3-102.

Hill, M. O., Bell, N., Bruggeman-Nannenga, M. A., Brugués, M., Cano, M. J., Enroth, J., Flatberg, K. I., Frahm, J.-P., Gallego, M. T., Garilleti, R., Guerra, J., Hedenäs, L., Holyoak, D. T., Hyvönen, J., Ignatov, M. S., Lara, F., Mazimpaka, V., Muñoz, J. and SÖDERSTRÖM, L. (2006): An annotated checklist of the mosses of Europe and Macaronesia. - J. Bryol. 28(3): 198-267. http://dx.doi.org/10.1179/174328206X119998 
HodgetTs, N. G. (2015): Checklist and country status of European bryophytes - towards a new red list for Europe. - Irish Wildlife Manuals, No. 84. National Parks and Wildlife Service, Department of Arts, Heritage and the Gaeltacht, Ireland, $125 \mathrm{pp}$.

Molnár, Zs. (1997): Szikesek. [Saline communities]. - In: Fekete, G., Molnár, Zs. and Horváth, F. (eds): Nemzeti Biodiverzitás-monitorozó Rendszer II. A magyarországi élőhelyek leírása, határozója és a Nemzeti Élőhely-osztályozási Rendszer. [National biodiversity monitoring system. II. Description and keys for the identification of Hungarian habitats and the national classification system of habitats.], Magyar Természettudományi Múzeum, Budapest, pp. 92-99.

ORBÁN, S. (1982): The bryoflora of the Hortobágy National Park and the adjoining conservation areas. - In: Szuj Kó-LACZA, J. (ed.): The flora of the Hortobágy National Park, Akadémiai Kiadó, Budapest, pp. 97-103.

PAPP, B. and RAJCZY, M. (1999): Bryophytes of the Kiskunság National Park and of the other parts of the Danube-Tisza Interfluve. - In: LöKös, L. and RAJCZY, M. (eds): The flora of the Kiskunság National Park, Cryptogams. Magyar Természettudományi Múzeum, Budapest, pp. 363-413.

PAPP, B. and RAJCZY, M. (2000): Bryophytes of saline-alkali areas of the Danube-Tisza Interfluve, Hungary. - Lindbergia 25: 134-139.

Papp, B., Erzberger, P. and Sabovljević, M. (2011): Microbryum floerkeanum (F. Weber \& D. Mohr) Schimp. In: Ellis, L. T. (ed.): New national and regional bryophyte records, 26. $-J$. Bryol. 33(1): 68. http://dx.doi.org/doi/10.1179/1743282010Y.0000000014

Papp, B., Natcheva, R., Erzberger, P. and Sabovljević, M. (2012): Didymodon sicculus, new to Bulgaria, Serbia and some notes on its ecology. - Nova Hedwigia 95(1-2): 221-226.

Ros, R. M., Mazimpaka, V., Abou-Salama, U., Aleffi, M., Blockeel, T. L., Brugués, M., Cros, R. M., Dia, M. G., Dirkse, G. M., Draper, I., El SaAdawi, W., Erda Ğ, A., Ganeva, A., Gabriel, R., González-Mancebo, J. M., Granger, C., Herrnstadt, I., Hugonnot,V., Khalil, K., KÜ Rschner, H., Losada-Lima, A., Luís, L., Mifsud, S., Privitera. M., Puglisi. M., Sabovljević, M., Sérgio, C., Shabbara, H. M., Sim-Sim, M., Sotiaux, A., Tacchi, R., VanDERPoORTEN, A. and Werner, O. (2013): Mosses of the Mediterranean, an annotated checklist. - Cryptogamie, Bryol. 34(2): 99-283. http://dx.doi.org/doi/10.782/cryb.v34.iss2.2013.99

Sabovljević, M., Cvetić, T. and Stevanović, V. (2004): Bryophyte red list of Serbia and Montenegro. - Biodiv. Conserv.13: 1781-1790. http://dx.doi.org/10.1023/B:BIOC.0000029338.97776.66

Sabovljević, M., Papp, B. and Szurdoki, E. (2010): New bryophyte records to some countries of the South-Eastern Europe. - Cryptogamie, Bryol. 31(3): 289-292.

Sabovljević, M., Tsakiri, E. and Sabovljević, A. (2008): Towards the bryophyte flora of Greece, studies in the Chalkidiki area (North Greece). - Cryptogamie, Bryol. 29: 143-155.

ŞTEFĂNUT, S. and GoIA, I. (2012): Checklist and red list of bryophytes of Romania. - Nova Hedwigia 95(1-2): 59-104. http://dx.doi.org/10.1127/0029-5035/2012/0044

Topić, J. and Vuković, N. (2010): Trpinja. - In: Nikolić, T., Topić, J. and Viković, N. (eds): Botanički važna područja Hrvatske. Prirodoslovno-matematički fakultet Sveučilišta u Zagrebu I Školska knjiga d.o.o., Zagreb, pp. 421-423.

Zaninović, K. (ed.) (2008): Klimatski atlas Hrvatske. (Climate atlas of Croatia). - DHMZ, Zagreb, $200 \mathrm{pp}$.

(submitted: 02.05.2016, accepted: 05.06.2016) 